\title{
Skeletal evolution in Marfan syndrome: growth curves from a French national cohort
}

\author{
Grégoire Benoist ${ }^{1}$, Florence Tubach ${ }^{1}$, Carine Roy ${ }^{1}$, Sabine Rioux ${ }^{1}$, Marlène Michelon-Jouneaux ${ }^{1}$, Bertrand Chevallier ${ }^{1}$, \\ Guillaume Jondeau ${ }^{1}$ and Chantal Stheneur ${ }^{1}$
}

BACKGROUND: To describe the growth patterns of children affected by Marfan syndrome (MFS) compared with those of unaffected children and to create growth charts.

METHODS: An observational study of children referred to the French National MFS Reference Centre. A total of 259 children carrying an FBN1 gene mutation and fulfilling Ghent 1 criteria (MFS group) and 474 mutation-negative sibling controls (nonMFS group) were evaluated. Both groups were compared with French-accepted reference nomograms (Reference group).

RESULTS: Boys and girls from the MFS group were significantly taller than those in the non-MFS group and in the reference group at all ages $(P<0.0001)$. But, MFS children's overgrowth reduced with age. At 17 years of age, the mean height (MFS vs. non-MFS) was $191.2 \pm 8.4 \mathrm{~cm}$ (+2.9SD) vs. $182.9 \pm 8.1$ (+1.6 SD) for boys and $178.3 \pm 7.6 \mathrm{~cm}(+2.7 \mathrm{SD}) \mathrm{vs}$. $169.5 \pm 6.8$ (+1.2 SD) for girls, respectively. By contrast, the mean BMI of children in the MFS group was similar to those in the non-MFS group and inferior to the values of French general population, evolving around - 1 SD.

CONCLUSION: Growth patterns differ in patients with an FBN1 mutation. Knowing the growth parameters should allow physicians to better counsel patients and detect the associated diseases. The provided curves could also help to predict the final height.

M arfan syndrome (MFS) (MIM 154700) is a connective tissue disorder with autosomal-dominant inheritance caused mostly by a mutation in the FBN1 gene (1). The prevalence of that disease is estimated at two or three cases per 10,000 individuals (2). MFS is characterized by a broad range of clinical manifestations involving the skeletal, ocular, cardiovascular, integument, pulmonary, and central nervous systems with great phenotypic variability (2-4). Cardiovascular involvement in the form of aortic aneurysm or a dissecting aorta is the most serious life-threatening aspect of the syndrome. The succession of classifications (Berlin, Ghent 1, and Ghent 2) illustrates the complexity of diagnosis, explaining the growing importance of genetic testing (5). In children, diagnosis is even more difficult because many manifestations are age-dependent and are therefore not yet present; so, the classification criteria are lacking the sensitivity (3). However, familial screening, facilitated by molecular biology testing, now allows early recognition of children with more limited clinical features.

Tall stature is a frequent reason to suspect MFS and to refer a child for evaluation, even though height is not part of any current international classification. It is further clinically relevant, as tall stature may also influence the functional outcome of children (6), and questions about the final height from families or MFS adolescents are recurrent in an external clinic. Pyeritz et al. (7) and Erkula et al. (8) have already proposed growth charts for American children with MFS, based on a retrospective review of MFS patients diagnosed on a clinical basis. In addition, growth charts for Korean children with MFS have recently been developed (9). However, growth of American or Asian children differs from that of European children, thereby making it important to have growth charts developed from a European sample of MFS children $(10,11)$.

The molecular defect may be of importance in the determination of height in patients. Specifically, patients carrying TGFBR2 mutations have a lower mean height than patients carrying an FBN1 mutation (12); this aspect was not taken into account in previous studies. Therefore, our study aims to describe the growth pattern (height, weight, BMI, and arm-span-to-height ratio) of French children with MFS carrying an FBN1 mutation in modern care, so as to provide updated special charts for MFS indicating the height according to age and gender.

\section{METHODS}

\section{Patients and Methods}

All subjects under 18 years of age who came to our multidisciplinary consultation at Bichat Hospital in Paris (CNR Marfan: Centre National de Référence pour le syndrome de Marfan et apparentés) between 1995 and 2010 were considered for this study. Children came to our clinic either because Marfan syndrome was suspected by a physician or the patient himself, or because children were relatives of MFS patients (familial screening is systematic in our clinic). During consultation, all children underwent an exhaustive clinical evaluation, including screening for features belonging to Ghent 1 criteria. Follow-up visits (yearly visits between 1995 and 2001 and a visit every 2 years thereafter), involving the same assessment, were

\footnotetext{
${ }^{1}$ Department of Pediatrics, Ambroise Paré Hospital, APHP, Boulogne-Billancourt, France. Correspondence: Chantal Stheneur (chantal.stheneur@apr.aphp.fr)

Received 8 May 2017; accepted 10 August 2017; advance online publication 27 September 2017. doi:10.1038/pr.2017.210
} 
Table 1. Comparison of skeletal features in children from the MFS group (left) and the non-MFS group (right) in each age group

\begin{tabular}{|c|c|c|c|c|c|c|c|c|c|c|c|c|c|c|c|}
\hline & \multicolumn{10}{|c|}{ Marfan group } & \multicolumn{5}{|c|}{ Non-Marfan group } \\
\hline & $\begin{array}{c}\text { Total } \\
N=259\end{array}$ & $\begin{array}{c}P \text {-value } \\
\text { MFS/ } \\
\text { non-MFS }\end{array}$ & $\begin{array}{c}0-6 \text { years } \\
N=103\end{array}$ & $\begin{array}{c}\text { P-value } \\
\text { MFS/ } \\
\text { non-MFS }\end{array}$ & $\begin{array}{l}7-9 \text { years } \\
N=101\end{array}$ & $\begin{array}{c}P \text {-value } \\
\text { MFS/ } \\
\text { non-MFS }\end{array}$ & $\begin{array}{c}10-14 \text { Years } \\
N=137\end{array}$ & $\begin{array}{c}P \text {-value } \\
\text { MFS/ } \\
\text { non-MFS }\end{array}$ & $\begin{array}{c}15-17 \text { Years } \\
N=114\end{array}$ & $\begin{array}{c}P \text {-value } \\
\text { MFS/ } \\
\text { non-MFS }\end{array}$ & $\begin{array}{c}\text { Total } \\
N=422\end{array}$ & $\begin{array}{c}0-6 \text { Years } \\
N=97\end{array}$ & $\begin{array}{c}\text { 7-9 Years } \\
N=68\end{array}$ & $\begin{array}{c}10-14 \text { Years } \\
N=138\end{array}$ & $\begin{array}{c}15-17 \\
\text { Years } \\
N=162\end{array}$ \\
\hline $\begin{array}{l}\text { Height }(\mathrm{cm}) \\
\text { mean } \pm S D\end{array}$ & $\begin{array}{c}144.9 \pm 29.8 \\
(N=259)\end{array}$ & 0.0007 & $\begin{array}{c}114.4 \pm 13.9 \\
(N=98)\end{array}$ & NS & $\begin{array}{c}141.5 \pm 9.0 \\
(N=100)\end{array}$ & $<0.0001$ & $\begin{array}{c}163.5 \pm 11.0 \\
(N=135)\end{array}$ & 0.009 & $\begin{array}{c}182.7 \pm 10.8 \\
(N=107)\end{array}$ & $<0.0001$ & $\begin{array}{c}152.7 \pm 27.6 \\
(N=400)\end{array}$ & $\begin{array}{c}111.4 \pm 13.0 \\
(N=83)\end{array}$ & $\begin{array}{c}135.6 \pm 9.3 \\
(N=67)\end{array}$ & $\begin{array}{c}159.7 \pm 12.0 \\
(N=126)\end{array}$ & $\begin{array}{c}177.2 \pm 9.3 \\
(N=159)\end{array}$ \\
\hline $\begin{array}{l}\text { Height (SD } \\
\text { for age) }\end{array}$ & $\begin{array}{l}3.6 \pm 1.8 \\
(N=252)\end{array}$ & $<0.0001$ & $\begin{array}{l}4.2 \pm 2.0 \\
(N=98)\end{array}$ & $<0.0001$ & $\begin{array}{l}3.9 \pm 1.5 \\
(N=100)\end{array}$ & $<0.0001$ & $\begin{array}{l}3.6 \pm 1.6 \\
(N=135)\end{array}$ & $<0.0001$ & $\begin{array}{l}2.6 \pm 1.4 \\
(N=107)\end{array}$ & $<0.0001$ & $\begin{array}{l}1.9 \pm 1.5 \\
(N=400)\end{array}$ & $\begin{array}{l}2.4 \pm 2.0 \\
(N=83)\end{array}$ & $\begin{array}{l}2.2 \pm 1.6 \\
(N=67)\end{array}$ & $\begin{array}{l}1.9 \pm 1.2 \\
(N=126)\end{array}$ & $\begin{array}{l}1.5 \pm 1.2 \\
(N=159)\end{array}$ \\
\hline $\begin{array}{l}\text { Weight }(\mathrm{kg}) \\
\text { mean } \pm \text { SD }\end{array}$ & $\begin{array}{c}35.9 \pm 19.3 \\
(N=236)\end{array}$ & $<0.0001$ & $\begin{array}{c}19.1 \pm 5.0 \\
(N=93)\end{array}$ & NS & $\begin{array}{c}29.7 \pm 7.7 \\
(N=95)\end{array}$ & NS & $\begin{array}{c}44.4 \pm 12.2 \\
(N=127)\end{array}$ & NS & $\begin{array}{c}62.3 \pm 12.9 \\
(N=103)\end{array}$ & NS & $\begin{array}{c}42.7 \pm 18.4 \\
(N=367)\end{array}$ & $\begin{array}{c}19.9 \pm 5.0 \\
(N=77)\end{array}$ & $\begin{array}{c}29.8 \pm 7.3 \\
(N=63)\end{array}$ & $\begin{array}{c}45.4 \pm 12.3 \\
(N=113)\end{array}$ & $\begin{array}{c}60.6 \pm 10.6 \\
(N=144)\end{array}$ \\
\hline $\begin{array}{l}\mathrm{BMI}\left(\mathrm{kg} / \mathrm{m}^{2}\right) \\
\text { mean } \pm \mathrm{SD}\end{array}$ & $\begin{array}{l}15.8 \pm 3.1 \\
(N=236)\end{array}$ & $<0.0001$ & $\begin{array}{c}14.4 \pm 1.7 \\
(N=93)\end{array}$ & $<0.0001$ & $\begin{array}{c}14.7 \pm 2.4 \\
(N=95)\end{array}$ & 0.0018 & $\begin{array}{l}16.4 \pm 3.0 \\
(N=127)\end{array}$ & 0.0031 & $\begin{array}{l}18.5 \pm 3.2 \\
(N=103)\end{array}$ & 0.04 & $\begin{array}{l}17.4 \pm 3.1 \\
(N=367)\end{array}$ & $\begin{array}{c}15.7 \pm 2.2 \\
(N=77)\end{array}$ & $\begin{array}{c}16.0 \pm 2.9 \\
(N=63)\end{array}$ & $\begin{array}{l}17.6 \pm 3.2 \\
(N=113)\end{array}$ & $\begin{array}{l}19.3 \pm 2.9 \\
(N=144)\end{array}$ \\
\hline $\begin{array}{l}\text { Arm/height } \\
\text { mean } \pm S D\end{array}$ & $\begin{array}{c}1.03 \pm 0.03 \\
(N=245)\end{array}$ & $<0.0001$ & $\begin{array}{c}1.02 \pm 0.03 \\
(N=93)\end{array}$ & $<0.0001$ & $\begin{array}{c}1.03 \pm 0.04 \\
(N=73)\end{array}$ & $<0.0001$ & $\begin{array}{c}1.04 \pm 0.03 \\
(N=108)\end{array}$ & $<0.0001$ & $\begin{array}{c}1.04 \pm 0.03 \\
(N=64)\end{array}$ & 0.0012 & $\begin{array}{c}1.02 \pm 0.03 \\
(N=362)\end{array}$ & $\begin{array}{c}1.00 \pm 0.04 \\
(N=70)\end{array}$ & $\begin{array}{c}1.00 \pm 0.02 \\
(N=60)\end{array}$ & $\begin{array}{c}1.02 \pm 0.03 \\
(N=106)\end{array}$ & $\begin{array}{c}1.03 \pm 0.03 \\
(N=136)\end{array}$ \\
\hline $\begin{array}{l}\text { Arm/ } \\
\text { height }>1.05\end{array}$ & $\begin{array}{c}29.4 \% \\
(N=245)\end{array}$ & $<0.0001$ & $\begin{array}{c}14.0 \% \\
(N=93)\end{array}$ & NS & $\begin{array}{c}21.9 \% \\
(N=73)\end{array}$ & 0.0018 & $\begin{array}{c}37.0 \% \\
(N=108)\end{array}$ & $<0.0001$ & $\begin{array}{c}46.2 \% \\
(N=65)\end{array}$ & $<0.0001$ & $\begin{array}{c}11.4 \% \\
(N=362)\end{array}$ & $\begin{array}{c}5.6 \% \\
(N=72)\end{array}$ & $\begin{array}{c}3.3 \% \\
(N=60)\end{array}$ & $\begin{array}{c}12.8 \% \\
(N=125)\end{array}$ & $\begin{array}{c}15.7 \% \\
(N=166)\end{array}$ \\
\hline $\begin{array}{l}\text { Scoliosis } \\
\text { angle }\left(^{\circ}\right) \\
\text { mean } \pm \text { SD }\end{array}$ & $\begin{array}{l}9.9 \pm 11.2 \\
(N=154)\end{array}$ & 0.0009 & $\begin{array}{l}5.7 \pm 6.6 \\
(N=50)\end{array}$ & 0.0008 & $\begin{array}{l}9.2 \pm 7.7 \\
(N=61)\end{array}$ & $<0.0001$ & $\begin{array}{c}11.0 \pm 9.9 \\
(N=83)\end{array}$ & $<0.0001$ & $\begin{array}{c}15.6 \pm 13.3 \\
(N=61)\end{array}$ & $<0.0001$ & $\begin{array}{l}5.3 \pm 5.8 \\
(N=297)\end{array}$ & $\begin{array}{l}2.7 \pm 1.4 \\
(N=61)\end{array}$ & $\begin{array}{l}4.2 \pm 3.9 \\
(N=41)\end{array}$ & $\begin{array}{l}5.0 \pm 6.0 \\
(N=98)\end{array}$ & $\begin{array}{l}6.9 \pm 6.6 \\
(N=122)\end{array}$ \\
\hline $\begin{array}{l}\text { Scoliosis } \\
\text { angle }>10^{\circ}\end{array}$ & $\begin{array}{c}33.8 \% \\
(52 / 154)\end{array}$ & 0.010 & $16.0 \%(8 / 50)$ & 0.01 & $\begin{array}{l}29.5 \% \\
(18 / 61)\end{array}$ & 0.007 & $\begin{array}{l}41.0 \% \\
(34 / 83)\end{array}$ & $<0.0001$ & $\begin{array}{l}59.0 \% \\
(36 / 61)\end{array}$ & $<0.0001$ & $\begin{array}{c}12.5 \% \\
(37 / 297)\end{array}$ & $1.6 \%(1 / 61)$ & $7.3 \%(3 / 41)$ & $\begin{array}{c}10.2 \% \\
(10 / 98)\end{array}$ & $\begin{array}{c}19.7 \% \\
(24 / 122)\end{array}$ \\
\hline
\end{tabular}

MFS, Marfan syndrome; NS, nonsignificant. 
proposed when MFS was diagnosed or could not be ruled out. Height was determined by placing the children with their backs against a wall, looking straight ahead, and with their arms hanging freely at their sides. Weight was obtained using electronic scales to the nearest $0.1 \mathrm{~kg}$; the children wore light clothing and no shoes. Arm span was measured from the tip of the third digit of the right hand to the third digit of the left hand, including the shoulder width; the children stood with arms stretched perpendicular to the body. The initiation of puberty was defined by the increase of the upper testicular volume to $4 \mathrm{ml}$ for boys (G2), and the development of breast buds for girls (S2). The bone age was compared with the atlas of Greulich and Pyle (13) during consultation.

Molecular biology (screening for an FBN1 mutation) was performed in the case of high clinical suspicion of MFS (the presence of at least one major and one minor Ghent 1 criteria) or the existence of a known mutation in the family.

Only families with an FBN1 mutation were considered for this study. Children carrying an FBN1 mutation who fulfilled the Ghent 1 criteria during follow-up were included in the "MFS group". Unaffected children (a mutation-negative sibling only) were included in the "non-MFS group" in order to get a modern nonselected control group. Any patient who had received a hormonal treatment for overgrowth was excluded (eight patients). All parents signed an informed consent form.

\section{Statistical Analysis}

The characteristics of children are reported by age stratum at consultation: 0-6 years old, 7-9 years old, 10-14 years old, and 1517 years old. Each child could contribute to more than one age stratum, but only once per age stratum (first visit during this stratum). These characteristics are expressed by frequencies and percentages for categorical variables, and by means and SD for continuous variables. Comparisons between children with MFS and those without MFS were performed in each stratum of age for categorical variables using chi-square or Fisher's exact test, and for continuous variables, Student's $t$-test or Wilcoxon's rank-sum test was conducted, as appropriate. Proband children were compared with non-proband children using the same statistical tests. The significance level was $5 \%$.
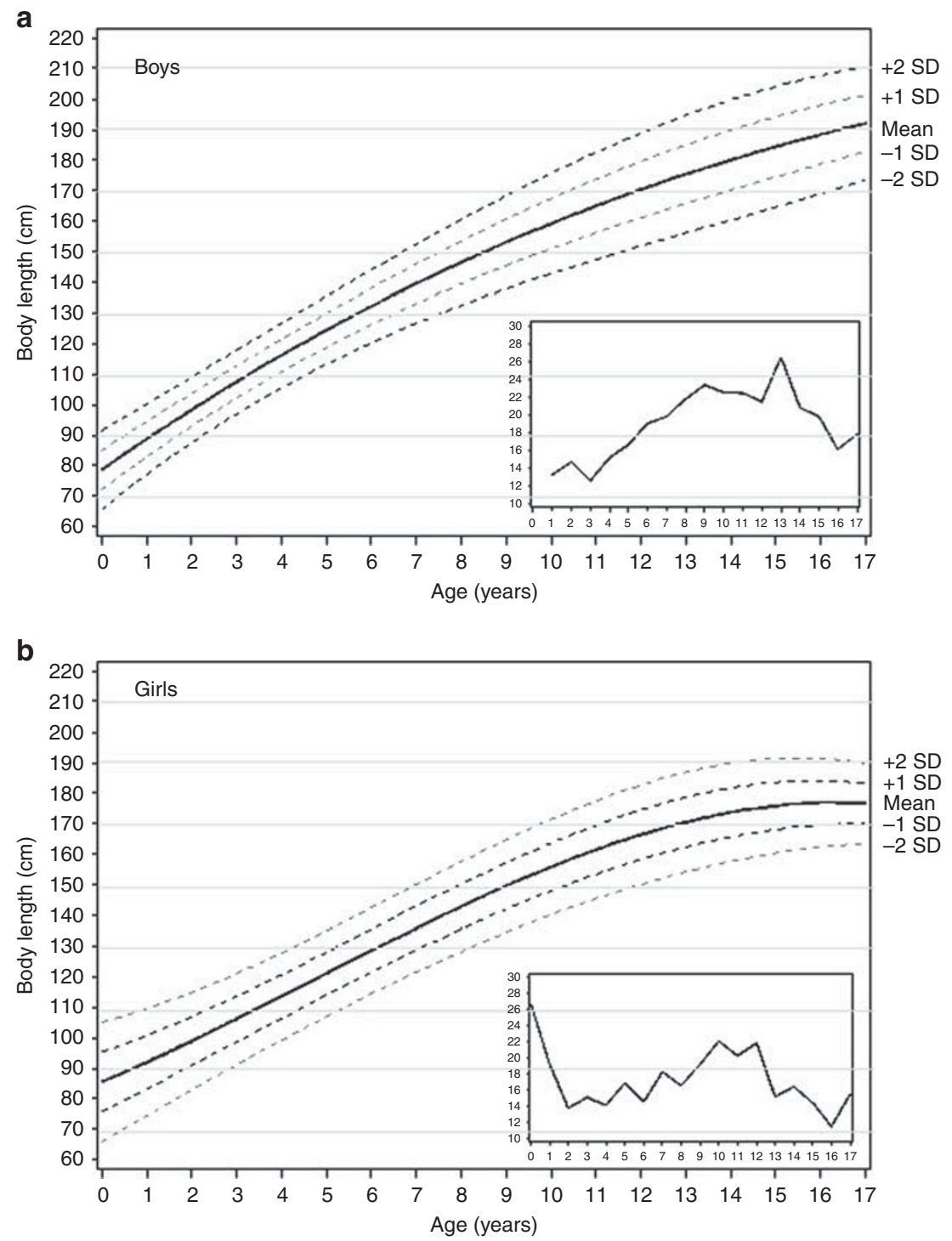

Figure 1. MFS charts of body length according to age and gender (a boys, b Girls) for MFS children carrying an FBN1 mutation (mean, \pm 1 SD, \pm 2 SD). The curves in boxes represent the delta of centimeters vs. age between the MFS group and the French general population (Sempe curves). 


\section{Articles | Benoist et al.}

The receiver-operating characteristic (ROC) curve and the Youden index (maximum potential effectiveness of a continuous data) were used to evaluate the best cut point for an arm-span-over-height ratio at different ages.

The height of boys and girls was plotted against the chronological age at 1-year intervals to compare the growth between children with MFS and those without MFS. Curves were smoothed (14), and the French reference growth curves from Sempe were added to the graphs for comparison (15). Sempe curves were chosen as they are still widely used in France; however, we also compared the data with the WHO curves. The average difference between the growth curve of children with MFS and the Sempe growth curve was plotted against their age.

Statistical analyses were performed using SAS software version 9.2 (SAS Institute, Cary, NC).

\section{RESULTS}

\section{Population}

The MFS group consisted of 259 children (134 boys) (fulfilling Ghent 1criteria and carrying an FBN1 mutation) with 850 visits ( 419 for boys and 431 for girls). The non-MFS group was made up of 422 children with 512 visits ( 278 boys) (Table 1).

\section{Clinical Presentation}

MFS group. A number of 103 (39.8\%) patients came for the first visit between the age of 0 and 6 years old, 49 (18.9\%) between 7 and 9 years old, 68 (26.2\%) between 10 and 14 years old, and 39 (15.1\%) between 15 and 17 years old. A family history of MFS was present in 158 (61.0\%) children.

Non-MFS group. Non-MFS group children were older at the first visit ( $11.1 \pm 4.7$ vs. $8.6 \pm 4.6$ years old; $P<0.0001)$. By contrast, the sex ratio was similar in the two groups (1.2 vs. 1.1 (nonsignificant)).

\section{Statural Growth}

Growth curves of boys and girls with MFS were plotted with the mean and standard deviations $( \pm 1, \pm 2)$ in Figure 1. In centimeters, the difference in height between children with MFS and the French reference increased until 13 years old in boys and 12 years old in girls, and then decreased (Figure 1, boxes). Assessed by standard deviation, boys in the MFS group's overgrowth reduced with age from $+4.2 \mathrm{SD}$ between 0 and 6 years old, to $+2.7 \mathrm{SD}$ between 15 and 17 years old (Table 1 and Figure 2). Therefore, a prediction at the age of 10 could lead to an overestimation of the final height by more than $8 \mathrm{~cm}$. For girls in the MFS group, the difference also decreased from +3.9 SD between 0 and 6 years old, to $+2.5 \mathrm{SD}$ between 15 and 17 years old. At 17 years of age, the mean height of the boys in the MFS group was $191.2 \pm 8.4 \mathrm{~cm}$ $(+2.9 \mathrm{SD})$ vs. $182.9 \pm 8.1 \mathrm{~cm}(+1.6 \mathrm{SD})$ in the non-MFS group and $178.3 \pm 7.6 \mathrm{~cm}(+2.7 \mathrm{SD})$ for girls in the MFS group vs. $169.5 \pm 6.8 \mathrm{~cm}(+1.2 \mathrm{SD})$ in the non-MFS group.

In probands, height was greater only in males at 10-14 years $(4.4 \pm 1.2 \mathrm{SD}$ above the Sempe mean vs. $3.5 \pm 1.7$ in non-probands) $(P=0.04)$ and $15-17$ years $(3.2 \pm 1.2 \mathrm{SD}$ above the Sempe mean vs. $2.4 \pm 1.5)(P=0.02)$.

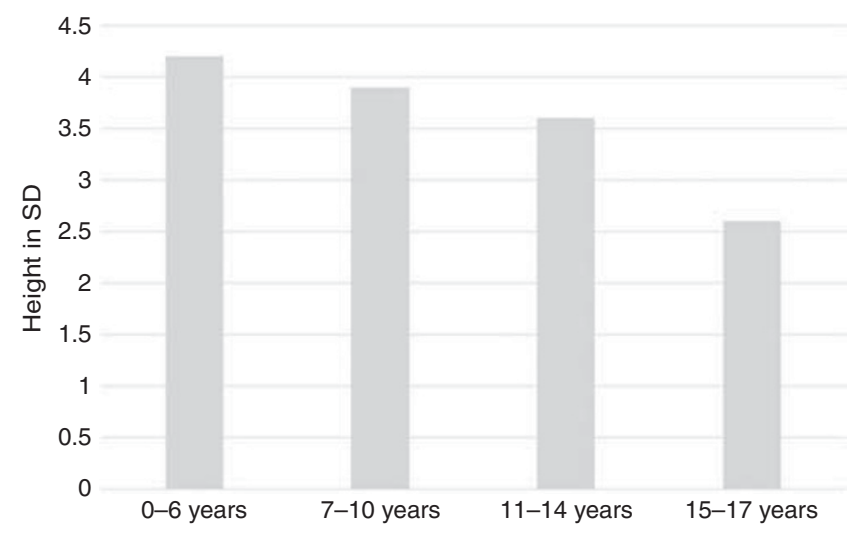

Figure 2. Reduction of overgrowth (expressed in SD) in MFS children in different age groups.

A comparison of children from the MFS group and children from the non-MFS group showed that boys and girls from the MFS group were significantly taller than boys and girls from the non-MFS group (Figure 3). But expressed in SD, the height difference between the two populations decreased from $+1.6 \mathrm{SD}$ in the $0-6$-year-old group to $+1.1 \mathrm{SD}$ in the $15-17$ year-old group.

\section{BMI}

In our MFS population, BMI increased slightly throughout the growth phase from $14.4 \pm 1.7(-1 \mathrm{SD})$ to $18.5 \pm 3.2 \mathrm{~kg} / \mathrm{m}^{2}$ $(-0.5 \mathrm{SD})$. The difference between the two groups (MFS vs. non-MFS) decreased significantly with age. In the 0-6-yearold section, the BMI difference between the MFS and nonMFS group was $1.3 \mathrm{~kg} / \mathrm{m}^{2}(<0.0001)$ and $0.8 \mathrm{~kg} / \mathrm{m}^{2}$, respectively, in the 15-17-year-old section $(P=0.04)$.

\section{Arm-Span-Over-Height Ratio and Scoliosis}

The mean value for the arm-span-over-height ratio was $1.03 \pm 0.03$ for children in the MFS group, but increased from $1.02 \pm 0.03$ when $0-6$ years old to $1.04 \pm 0.03$ when 15-17 years old. The percentage of children in the MFS group with a ratio $\geq 1.05$ increased accordingly in each age group from $14 \%$ when $0-6$ years old; $21.9 \%$ when $7-9$ years old; $37.0 \%$ when $10-14$ years old; and to $46.2 \%$ when $15-17$ years old, illustrating the altered sensitivity of skeletal criteria in young children. A comparison between children from the MFS and non-MFS groups showed that the mean arm-span-to-height ratio was significantly greater in those with MFS than those without MFS (Table $1 ; P<0.0001$ ) for the whole population and in each age group. Also, the percentage of non-MFS group children with a ratio $>1.05$ remained significantly lower than the percentage in children with MFS in all age groups even if it increased with age. Using ROC curves, the maximum Youden index found a value of 1.03 for the whole population, evolving from 1.00 for 0-6 years old; 1.02 for 7-9 years old; 1.04 for 10-14 years old; and to 1.05 for 15-17 years old children. By grouping 

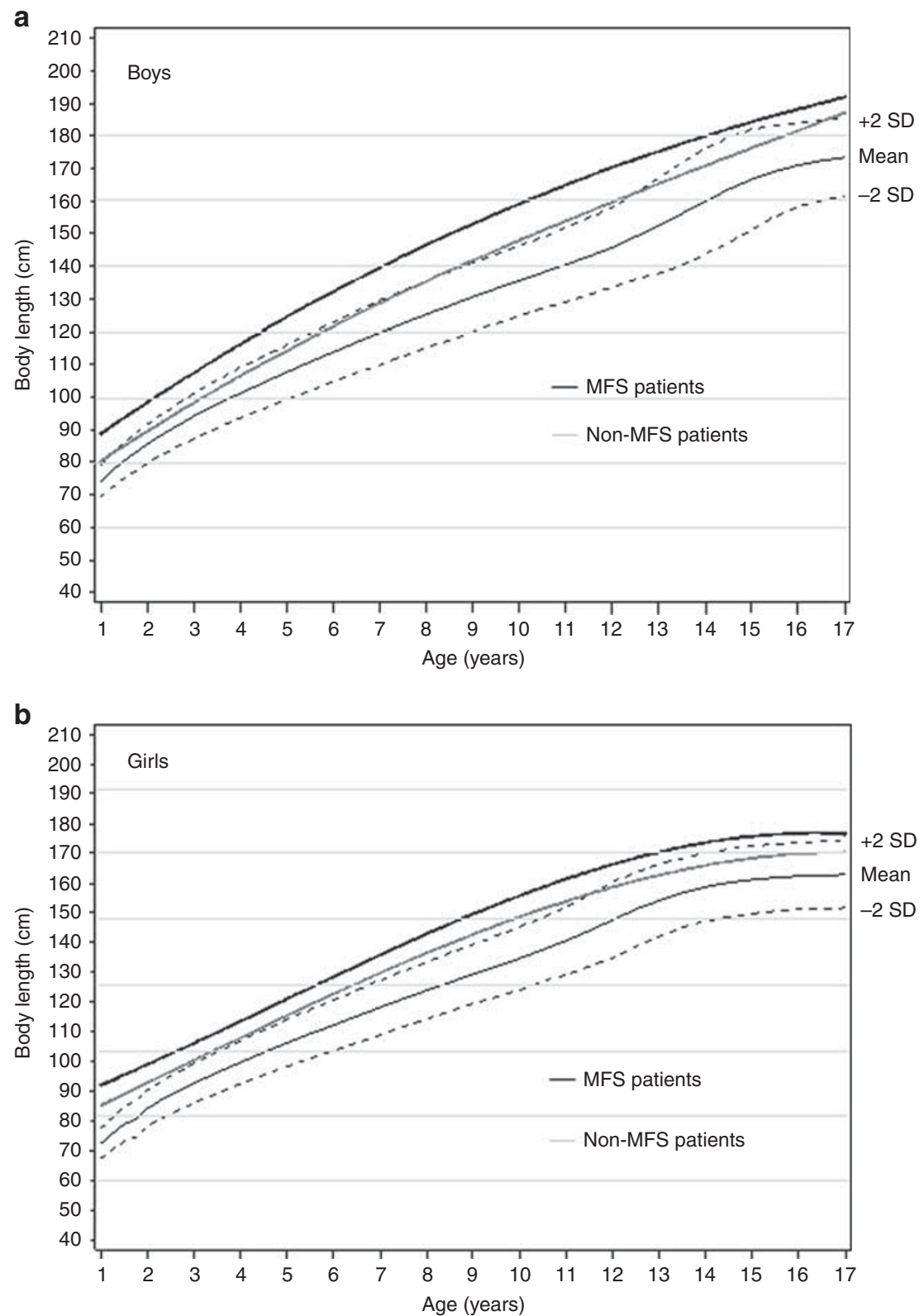

Figure 3. Body length (cm) vs. age (years) for male (a) or female (b) children with MFS carrying an FBN1 mutation (black curves), or unaffected parents (control, gray curves) plotted on the graph with the French general population (plain thin lines for the mean and dotted lines for \pm 2 SD) as determined by Sempe.

the first two classes (0-9 years old), the maximum Youden index was 1.01 (sensibiliy $=0.65$, specificity $=0.65$ ).

The mean angle for scoliosis increased from $5.7 \pm 6.6^{\circ}$ to $15.6 \pm 13.3^{\circ}$ in MFS children. Compared with the non-MFS group, the angle for scoliosis was significantly greater in each age section in MFS groups (Table 1). When a cutoff of $10^{\circ}$ was chosen, the prevalence of a scoliosis was 10 times more frequent in children aged $0-6$ years old ( $16.0 \%$ vs. $1.6 \%)$; this ratio decreased progressively with age to a ratio of 3 at the age of $15-17$ years old $(59.0 \%$ vs. $19.7 \%)$. When a cutoff of $20^{\circ}$ was chosen (as suggested in the most recent Ghent 2 criteria), none of the non-MFS group children under 10 years old had positive scoliosis. The prevalence of scoliosis was 6.3 times higher in the MFS group children aged 10-14 years and similarly decreased to a ratio of 3.2 at the age of $15-17$ years.

\section{Puberty Onset}

Puberty onset occurred significantly earlier in girls from the MFS group when compared with girls from the non-MFS group $(10.4 \pm 1.6$ years vs. $11.5 \pm 1.2$ years; $P=0.04)$. No differences were observed in the boys, but this may have been due to lack of power (less data available for boys).

\section{DISCUSSION}

Our study provides, for the first time, standards for height, weight, BMI, and arm span in children (boys and girls) 


\section{Articles | Benoist te al.}

carrying an FBN1 mutation and fulfilling Ghent 1 criteria. Previous studies have reported the growth pattern of children with a diagnosis of Marfan syndrome based on clinical grounds. This could be a major limitation as the clinical features of MFS appear with age, meaning that clinical diagnosis likely selects the more severe patients. Furthermore, the reason for referral (often skeletal features in our experience) may bias the sample selected, and deriving growth charts from a selected population may be of concern when making growth predictions in an unselected population (7-9).

One of the reasons for the inclusion of the Sempe curve is that currently in France, it is a more frequently used growth chart. A very recent French study (11) containing the data of 82,151 measurements available for 27,257 children in different age groups from birth to 18 years shows that the current French population of children was on average 0.5 standard deviations taller than the French reference population and was in fact closer to the WHO growth charts, except for girls after 15 years of age. In addition, the overgrowth present with MFS decreases with puberty when expressed in SD with both the Sempe curves and the WHO curves. The mean height that we report for our control group is $+1.2 \mathrm{SD}$ for girls and $+1.6 \mathrm{SD}$ for boys. We cannot explain the overgrowth of the non-affected sibling. Further studies would be interesting to confirm these data in mutation-negative siblings.

Interestingly, the final height of males with MFS is almost identical in different countries: $191.2 \pm 8.4 \mathrm{~cm}$ in France, $191.4 \pm 5.2 \mathrm{~cm}$ in Korea (9), and $191.3 \pm 9.0 \mathrm{~cm}$ (8) in the United States. This is true despite the difference in men's final height in each general population (174.4 vs. 173.3 and $176.7 \mathrm{~cm}$, respectively), suggesting that the presence of Marfan syndrome results in a similar height, regardless of the geographic origin or the genetic background. By contrast, the final height of females with MFS differs according to the country: $178.3 \pm 7.6 \mathrm{~cm}$ in France, $176.2 \pm 5.3 \mathrm{~cm}$ in Korea, and $175.4 \pm 8.2 \mathrm{~cm}$ in the United States; in the general population, the final height in females is $162.5,160.7$, and $163.1 \mathrm{~cm}$, respectively. The reason for this observation is unclear.

Although an observational and retrospective study, data were collected prospectively, and measures were standardized and obtained by pediatricians with extensive experience treating this pathology. All patients seen in the Marfan CNMR were included in the register if they belong to a family with an FBN1 mutation and meet the criteria. The familial screening is systematic in our clinic, and therefore should minimize the selection bias toward severity that can be observed when probands are overrepresented. This is illustrated by the fact that children with MFS were taller and presented a greater arm-span-over-height ratio. The results are therefore relevant to practice in the general population.

As it is now possible to propose treatments to limit the height in children when the predicted adult height is excessive, the ability to reliably determine the final height is important. In France, such a treatment is proposed if the final height exceeds $185 \mathrm{~cm}$ for girls and $200 \mathrm{~cm}$ for boys according to a regulatory agency (16). The normograms reported in this study could be used to predict growth, an adult's height, and make an appropriate decision on the use of a growth limitation therapy in patients with an FBN1 mutation.

Usually, the representation of a patient with MFS is an extremely lean person. However, in our study, the mean BMI value evolves from $-1 \mathrm{SD}$ to $-0.5 \mathrm{SD}$, indicating that a low BMI may not be as severe as expected in the MFS population except perhaps in younger patients.

Lastly, we report the arm-span-over-height ratio throughout childhood. In the general population, the arm-span-overheight ratio that tends to increase with age during childhood, is higher in boys than in girls, and remains around a mean value of $1.00 \pm 0.02(17,18)$. Our results are in accordance with the previous studies $(1,19-21)$ reporting that, in the MFS population, this ratio is significantly higher than that in the non-MFS population; however, evolution with age is similar. Therefore, the cutoff ratio should be adapted with age, and we propose that before the age of 10 years, the arm-span-overheight ratio should be considered as a diagnostic criterion for MFS when it is $>1.01$.

Our study has some limitations. Including only FBN1 mutation carriers fulfilling Ghent 1 criteria may not completely preclude a bias toward more severe cases of FBN1 mutation, as the milder forms may remain unrecognized; however, this is limited by the systematic familial screening performed in our center, including mutation screening. We decided to keep children with scoliosis for the analysis of height, and not adjust the height values with the use of correction equations as proposed by some (22). In fact, scoliosis may decrease the height and may have attenuated the difference between MFS and non-MFS populations.

We integrated our data with "visits" as the unit. We used both repeated data for each child (as in a longitudinal study) and several examinations of different subjects in the same age group (as in a cross-sectional study). A longitudinal prospective study with a larger group, a single observer, and the same equipment, would have been optimal, but due to time constraints and practical limitations, it is not feasible. All the growth information was collected in our center, which explains why the data are scarcer at the extremes of curves (for example, length at birth because of the age for diagnosis).

\section{CONCLUSION}

The charts generated in this study for MFS patients carrying an FBN1 mutation can be useful for pediatricians to appreciate growth in these children as precisely as that in unaffected children, to predict a final height, monitor growthreducing therapy, and even screen a suspected case for MFS. The physical symptoms, particularly the height, are a major source of psychological suffering in MFS (6); reassuring parents and children regarding what to expect can help them to better cope with their illness. 


\section{STATEMENT OF FINANCIAL SUPPORT}

This work was supported by grants from the French Ministry of Health (grant Programme Hospitalier de Recherche Clinique 2010 AOM09093) and the Agence Nationale pour la Recherche (ANR 2010 BLAN 1129).

Disclosure: The authors declare no conflict of interest.

\section{REFERENCES}

1. Faivre L, Collod-Beroud G, Loeys BL, et al. Contribution of molecular analyses in diagnosing Marfan syndrome and type I fibrillinopathies: an international study of 1009 probands. J Med Genet. 2008;45:384-90.

2. Judge DP, Dietz HC. Marfan's syndrome. Lancet 2005;366:1965-76.

3. Stheneur C, Tubach F, Jouneaux M, et al. Study of phenotype evolution during childhood in Marfan syndrome to improve clinical recognition. Genet Med. 2014;16:246-50.

4. Stheneur C, Collod-Beroud G, Faivre L, et al. Identification of the minimal combination of clinical features in probands for efficient mutation detection in the FBN1 gene. Eur J Hum Genet 2009;17:1121-8.

5. von Kodolitsch Y, De Backer J, Schuler H, et al. Perspectives on the revised Ghent criteria for the diagnosis of Marfan syndrome. Appl Clin Genet 2015;8:137-55.

6. Van Tongerloo A, De Paepe A. Psychosocial adaptation in adolescents and young adults with Marfan syndrome: an exploratory study. J Med Genet 1998;35:405-9.

7. Pyeritz RE, Murphy EA, Lin SJ, Rosell EM. Growth and anthropometrics in the Marfan syndrome. Prog Clin Biol Res 1985;200:355-66.

8. Erkula G, Jones KB, Sponseller PD, Dietz HC, Pyeritz RE. Growth and maturation in Marfan syndrome. Am J Med Genet 2002;109:100-15.

9. Kwun Y, Kim SJ, Lee J, et al. Disease-specific growth charts of Marfan syndrome patients in Korea. J Korean Med Sci 2015;30:911-6.
10. Rosario AS, Schienkiewitz A, Neuhauser H. German height references for children aged 0 to under 18 years compared to WHO and CDC growth charts. Ann Hum Biol 2011;38:121-30.

11. Scherdel P, Botton J, Rolland-Cachera MF, et al. Should the WHO growth charts be used in France? PLoS ONE 2015;10:e0120806.

12. Attias D, Stheneur C, Roy C, et al. Comparison of clinical presentations and outcomes between patients with TGFBR2 and FBN1 mutations in Marfan syndrome and related disorders. Circulation 2009;120:2541-9.

13. Greulich W, Idell Pyle S. Radiographic Atlas of Skeletal Development of the Hand and Wrist. Standford University Press, 1950.

14. Flegal KM. Curve smoothing and transformations in the development of growth curves. Am J Clin Nutr 1999;70:163s-5s.

15. Sempe M PG, Roy-Pernot M-P [Auxology Method and Sequences]. Paris: Laboratoire Theraplix, 1979.

16. Bouvatier C. La grande taille à l'adolescence. Adolesc Méd 2014;8:22-6.

17. Reeves SL, Varakamin C, Henry CJ. The relationship between arm-span measurement and height with special reference to gender and ethnicity. Eur J Clin Nutr 1996;50:398-400.

18. Engstrom FM, Roche AF, Mukherjee D. Differences between arm span and stature in white children. J Adolesc Health Care 1981;2:19-22.

19. Sponseller PD, Erkula G, Skolasky RL, Venuti KD, Dietz HC 3rd. Improving clinical recognition of Marfan syndrome. J Bone Joint Surg Am 2010;92:1868-75.

20. Lipscomb KJ, Clayton-Smith J, Harris R. Evolving phenotype of Marfan's syndrome. Arch Dis Child 1997;76:41-6.

21. Faivre L, Collod-Beroud G, Loeys BL, et al. Effect of mutation type and location on clinical outcome in 1,013 probands with Marfan syndrome or related phenotypes and FBN1 mutations: an international study. Am J Hum Genet 2007;81:454-66.

22. Kono K, Asazuma T, Suzuki N, Ono T. Body height correction in scoliosis patients for pulmonary function test. J Orthop Surg 2000;8:19-26. 